Franck $^{3}$ (Berlin) described an elevation of temperature amounting to $0.3^{\circ}-0.4^{\circ} \mathrm{C}$. occurring before onset of the menses in tubercular women and allowing their onset to be foretold. He states that this elevation is only seen in rectal measurement, but this is not so, since all Turban's observations are temperature readings taken for ten minutes in the mouth. And when the elevation occurs in apparently healthy women he suspects a concealed focus of disease in the genital tract or elsewhere.

Kraus ${ }^{4}$ (Wienerwald) admits the occurrence of a premenstrual elevation in many healthy women and found it in two-thirds of his tubercular cases. Its duration varies from two days to two weeks, and it gives rise to no symptoms. It may be the first and only expression of a concealed focus. Sometimes it is associated with an increase of râles, resembling a tuberculin injection, and then disappears with clinical improvement.

Sabourin ${ }^{3}$ states that the premenstrual elevation is nearly constant and is of real value in diagnosis. Other references are given in Turban's paper, and the subject has recently been gone into by Dr. Vere Pearson in The LANCEx of Sept. 18th, 1909, and by Dr. Constance Colley in a paper of much interesting detail, illustrated by very striking temperature charts, in the Magazine of the London School of Medicine for Women, October, 1909.

I am, Sir, yours faithfully,

Arosa, Switzerland, March 9th, 1910. EgBERT C. MoRLAND.

\section{CONGENITAL INTESTINAL ATRESIA.}

\section{To the Editor of THE LANCET.}

SiR,-With reference to articles in THE LANCET on Congenital Intestinal Obstruction by Dr. N. I. Spriggs (Jan. 8th, 1910) and Congenital Intestinal Atresia by Mr. H. S. Clogg (Dec. 24th, 1904) I would invite the attention of collectors to a case (described by me in the Indian Medical Gazette of April, 1889) in which a complex atresia occurred 60 inches from the pylorus. Its nature in connexion with Meckel's diverticulum was discussed. The specimen is in the museum of the Medical College, Calcutta.

Ferozepore, Feb. 24th, 1910

$$
\text { I am, Sir, yours faithfully, }
$$

$$
\text { J. R. ADIE. }
$$

\section{THE EARLY DIAGNOSIS OF CANCER OF THE STOMACH. \\ To the Editor of THE LANCET.}

SIR,-I do not wish to shock Dr. W. Gordon's feelings in the least, especially after his courtesy in forwarding me an advance copy of his long letter to you, but I am bound to tell him that so far as this particular subject, the early diagnosis of cancer of the stomach, the only one with which I have to deal, is concerned, I do not attach the least importance to the authoritative opinions of the eminent clinicians whom he quotes. Facts with which they were not acquainted have come to light since those opinions were formed. Had they known those facts, I have no doubt they would have revised those opinions, as I have no doubt Dr. Gordon will revise his.

I note that in his letter to you Dr. Gordon takes no notice of Willan's and McCarty's results, published in the Amerioan Journal of Medical Soiences, quoted by Mr. Hey Groves. I was not aware of these at the time my paper was written, but they confirm the conclusions at which I arrived in every single particular. These are facts, very definite facts, as Mr. Hey Groves calls them. The specimens were not selected. All the specimens of stomach diseases removed by the brothers Mayo were investigated. The cases were not selected, except of course so far that no case demonstrably incurable was operated upon. The result is conclusive; no fair-minded man can doubt it; they prove my point. It is of course open to Dr. Gordon to prove that cases of carcinoma of the stomach which do not come to the surgeon at all, or which only come when it is too late, have not originated from old gastric ulcers or irritated scars. But he

3 Zur Frage des Menstruationsfiebers tuberkuloser Frauen, Berliner Klinische Wochenschrift, 1905, No. 42

4 Über praemenstruelle Temperatursteigerung bei Lungentuberkulose, Wiener Medicinische Wochenschrift, 1905, No. 13. 5 Revue de Médecine, March, 1905. must prove it. Mere quotation from authorities who, however eminent, were not acquainted with what we know now is not proof. When he has done this I will deal with the rest of his letter.-I am, Sir, yours faithfully,

Wimpole-street, W., March 12th, 1910 C. Mansell Moullin.

\section{INTRACRANIAL PSEUDO-TUMOURS.} To the Editor of THE LANCET.

SIR,-In the interesting annotation published under this title in THE LANCET of March 5th (p. 662) it is stated as "no doubt conceivable that a small tumour may become latent and the symptoms due to its presence may vanish." May I venture to suggest that this proposition is something more than "conceivable," as there are clinical and pathological records which definitely establish its truth. Leaving on one side the cases in which an intracranial tumour has been found on post-mortem examination, though no evidences of its existence had been observed during life, there are other records showing a clinical history of considerable cerebral disturbance followed by a more or less prolonged period of recovery, and later, by the discovery of an intracranial growth on necropsy. Such cases are certainly unusual, but they are sufficient to afford demonstrative proof that a tumour may cause active and alarming symptoms and yet may pass into a condition of quiescence. Obviously this fact does not contradict your suggestion that some intracranial conditions other than tumour may produce a clinical picture identical with that frequently caused by tumour. But it does suggest that among the cases for which such an explanation is invoked there may well be some in which tumour after all is the correct diagnosis. Series of cases similar to those described by Dr. Finkelnburg and Dr. Eschraum have frequently attracted attention in this country, and are to be met with notably in the writings of Dr. Hughlings Jackson and Sir Jonathan Hutchinson; in addition, many individual cases of the same order have been recorded. Some years ago I made an endeavour to collect these records (Glasgow Hospital Reports, 1899), and at the same time I added notes of nine cases which had come under my own observation. The consideration of the whole of the evidence leads almost inevitably to your conclusion "that there is some pathological condition with which we are not familiar which simulates intracranial tumour" and yet leaves room for the conviction that recovery more or less complete from "the ordinary triad of tumour symptoms" is not necessarily inconsistent with the diagnosis of intracranial growth. That one of the simulating conditions is at times thrombosis of the intracranial veins and sinuses $I$ bave striven to show elsewhere ${ }^{1}$ but even if this and other conditions are allowed it still unfortunately remains true that there is no certain and conclusive sign by which to determine in an individual case exhibiting "the ordinary triad of tumour symptoms," whether such symptoms are dependent on tumour or on some other condition. My immediate point, however, is to support the proposition that these symptoms, even when caused by a tumour within the skull, may more or less completely cease and disappear.

$$
\begin{aligned}
& \text { I am, Sir, yours faithfully, } \\
& \text { C. O. HAWTHORNe. }
\end{aligned}
$$

\section{THE "PERFECT WOMAN":A DIS- CLAIMER. \\ Tho the Editor of THE LANCET.}

SIR,-An offensive poster has recently been placarded in Piccadilly-circus stating that we have examined "La Milo" and found her to be a perfect life. Will you kindly state in your next issue that this poster has been published without our knowledge or consent?

We examined "La Milo" about two years ago and found her to be an ordinary healthy woman, like a million or two other women in England. She was therefore recommended for acceptance for insurance. Neither she nor any one else was informed that she was perfect, bat her acceptance was merely notified in the nsual way.

We are, Sir, yours faithfully,

HAROLD J. JoHnson, \} Principal Medical Alifred M. Gossage, $\}$ Officers.

Gresham Life Assurance Society, Limited,

St. Mildred's House, Poultry, F.C., March 15th, 1910. 